\title{
CONTEMPLATION OF VARIOUS ROUTING PROTOCOLS FOR WIRELESS MESH NETWORKS
}

\author{
Himani $^{1}$, Er. Lal Chand Panwar ${ }^{2}$
}

\begin{abstract}
The wireless mesh networks are self configuring and decentralized in nature. Due to decentralized architecture of the network, mobile nodes can join or leave the network when they want and lead to raise the issue of security, routing and quality of service. In this paper, various routing protocols have been addressed in terms of various parameters. The routing protocols are broadly classified into reactive, proactive and hybrid type of routing. It is been analyzed that reactive routing protocols performs well in terms of bandwidth consumption.
\end{abstract}

Keywords: Mesh networks, routing, QoS, Reactive, proactive and hybrid

\section{INTRODUCTION}

The wireless mesh network is the combination of adhoc networks and it contains mesh portals which increase its coverage area [1].Wireless mesh networks are more advantageous than other wireless networks; these networks consists of easy deployment, greater reliability, self-configuration, self-healing and scalability.

Basically two types of nodes are present in Wireless Mesh Networks and these nodes are: Mesh routers and Mesh clients. Mesh routers are not mobile so they perform specific functions to support mesh networking. Mesh routers act as backbone for clients. Mesh routers have different wireless interfaces which can be implemented on either the same or different wireless access technologies. Mesh clients [2] have additional functions for mesh networking and can also work as routers. Mesh client has only one interface. Mesh clients have a higher variety of devices compared to mesh routers.

Routing plays an important role to forward data packet from source to destination node. The Wireless Mesh routing protocols are categorized in three different protocols and these are proactive routing, reactive routing and hybrid routing protocols.

In proactive routing protocols all the paths are created between source node and destination node, whether there is a need to transmit data or not. This type of routing protocols is also called table-driven methods. By Continuous evaluation of routes, routing information is updated by maintaining consistency. The main benefit of proactive routing protocols [3] is that nodes can quickly access route information and path is established.

In reactive routing protocols [3] on demand establishment of paths is created. These reactive methods are also called ondemand methods. When the source node required transferring data to a destination node initialization of route discovery process takes place. The discovery process terminates either when a route has been found or not.

Hybrid routing protocols are the combination of merits of proactive and reactive routing protocols by overpowering their demerits by discovering efficient routes, without having large number of control overheads. It establish diverse routing protocol in different part of the infrastructure of WMNs i.e. reactive protocols for the ad hoc network area while proactive protocols are employed in wireless backbone [5].

Routing plays an important factor to forward the data packet from source node to destination node. To provide efficient performance, routing metrics must satisfy basic requirements these are scalability, reliability, flexibility, throughput, load balancing, congestion control and efficiency.

\section{LITERATURE REVIEW}

Seongkwan Kim, (2009) proposed the technique which is based on an offline routing scheme [12] by comparing its end-toend link quality metrics (ETX and ETT) and throughput performance. Various modifications are also made in routing protocols (AODV, OLSR and HWMP) so that they operate better in wireless mesh environment. Author also provide a synthetic view of the performance dynamics of wireless mesh networks and the components that impact the performance, each of which cannot give the complete analysis for the network behavior by itself.

K.P. Vijayakumar, (2012) proposed the technique which is based on the theoretical details of variety of routing protocols that are proactive routing, reactive routing and hybrid routing. These protocols are used in wireless mesh networks and are used to identify the performance of these routing protocols [13]. The performance is done with respect to load balancing, packet delivery ratio, congestion network overhead, throughput and mobility of nodes.

\footnotetext{
${ }^{1}$ Department of Computer Engineering, Punjabi University, Patiala, Punjab, India

${ }^{2}$ Department of Computer Engineering, Punjabi University, Patiala, Punjab, India
} 
P.Selvakumar, (2012) proposed the technique which shows the comparison of mobile ad-hoc network routing protocols[15] TORA, AODV and DSR. Author also compared the performance of these routing protocols on the basis of metrics packet delivery ratio, throughput, end-to-end delay and routing head.

Carlos Lozano-Garzon, (2015) describes the distribution of N-to-1 multipath routing for Wireless Sensor Networks[16] based on Multi-Objective Optimization problem, where three functions (hop count, energy consumption and free space loss) were optimized and aim to do efficient use of the energy in the network and decrease the packet loss.

Ahmed Al-Saadi, (2015) proposed the technique about a heterogeneous metropolitan area network architecture [17] that joins an IEEE 802.11 wireless mesh network with a long-term evaluation (LTE) network. Also, another heterogeneous routing protocol and a routing algorithm based on reinforcement learning called Cognitive. Heterogeneous Routing (CHR) is proposed to choose the appropriate transmission technology based on parameters from every network. The simulation results demonstrate that the proposed network accomplishes an increase of up to $200 \%$ increase in throughput compared with Wi-Fijust networks or LTE-only networks.

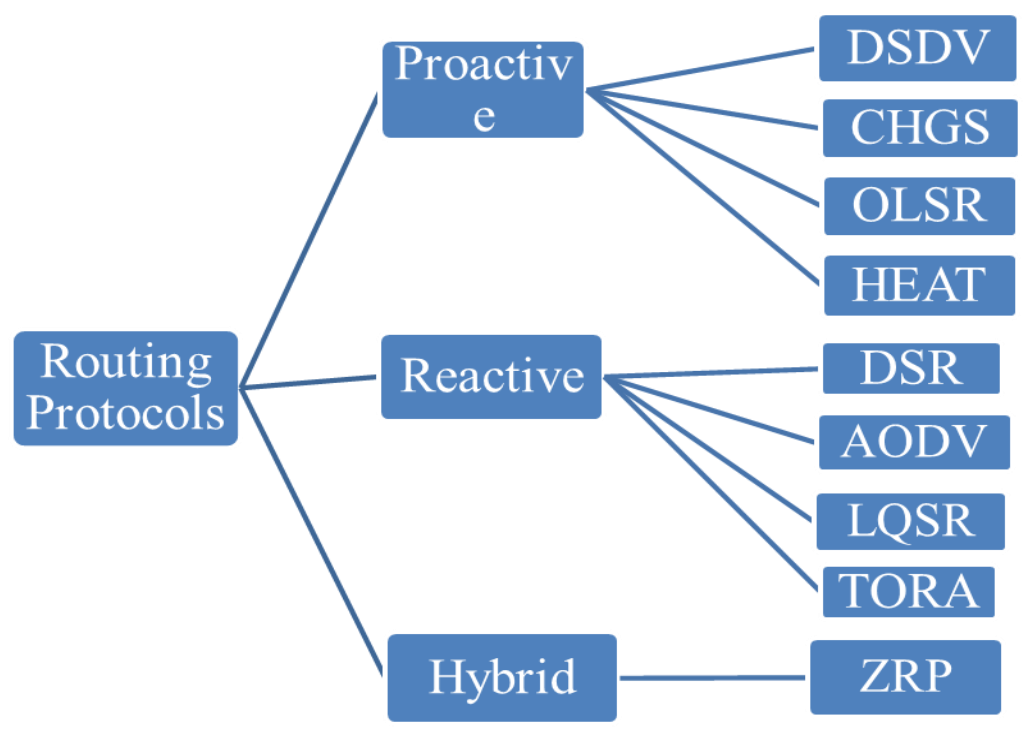

\section{TAXONOMY OF ROUTING PROTOCOLS}

The above taxonomy shows the various routing protocols categorized as proactive routing protocols, reactive routing protocols and hybrid routing protocols. These protocols further categorized as DSDV (Destination Sequenced Distance Vector) protocol, CGSR (Cluster head Gateway Switched Routing) protocol, OLSR (Optimized Link State Routing) protocol, Scalable routing using HEAT protocol, DSR (Dynamic Source Routing) protocol, AODV (Ad hoc On demand Vector Routing) protocol, LQSR (Link Quality Source Routing) protocol, TORA (Temporally Routing Algorithm), ZRP (Zone Based Routing Protocol). 


\begin{tabular}{|c|c|c|c|}
\hline Category & Protocol Name & Description & Outcome \\
\hline \multirow[t]{3}{*}{ Proactive Routing } & $\begin{array}{l}\text { CGSR known as } \\
\text { Clusterhead Gateway } \\
\text { Switched Routing }\end{array}$ & $\begin{array}{l}\text { This protocol is based } \\
\text { on Bellman-Ford } \\
\text { routing algorithm. This } \\
\text { algorithm maintains a } \\
\text { routing table by listing } \\
\text { all the shortest paths to } \\
\text { its destination node. } \\
\text { CGSR protocol is based } \\
\text { on DSDV principle } \\
\text { where number of nodes } \\
\text { is found into clusters } \\
\text { and each cluster [5] uses } \\
\text { cluster head (CH). CH } \\
\text { is used to forward data } \\
\text { packet from source node } \\
\text { to destination node. }\end{array}$ & $\begin{array}{l}\text { This algorithm balances } \\
\text { the traffic load using } \\
\text { load balancing metric } \\
\text { and avoid overloaded } \\
\text { areas using Expected } \\
\text { transmission time } \\
\text { (ETT). }\end{array}$ \\
\hline & $\begin{array}{l}\text { 4. Scalable Routing using } \\
\text { HEAT Protocol }\end{array}$ & $\begin{array}{l}\text { In OLSR protocol [6] } \\
\text { each node sends its link } \\
\text { state information to all } \\
\text { other nodes in the } \\
\text { available network. } \\
\text { Mainly two operations } \\
\text { are performed and these } \\
\text { operations are update } \\
\text { and maintain the } \\
\text { information which } \\
\text { present in the routing } \\
\text { table. } \\
\text { This HEAT algorithm is } \\
\text { based on properties of } \\
\text { temperature fields. } \\
\text { General feature of this } \\
\text { algorithm is that routing } \\
\text { is done with respect to } \\
\text { length and robustness of } \\
\text { the available path and } \\
\text { construction of nodes by } \\
\text { maintaining } \\
\text { communication between } \\
\text { the neighboring nodes. }\end{array}$ & $\begin{array}{l}\text { An important aspect is } \\
\text { used by this algorithm } \\
\text { is Multi point relays } \\
\text { (MPR) which decreases } \\
\text { the flooding overhead } \\
\text { and leads to sending of } \\
\text { packets more } \\
\text { efficiently. }\end{array}$ \\
\hline & $\begin{array}{l}\text { 1. DSR known as Dynamic } \\
\text { Source Routing Protocol }\end{array}$ & $\begin{array}{l}\text { DSR protocol is based } \\
\text { on source routing which } \\
\text { works on route } \\
\text { discovery and route } \\
\text { maintenance. If Route } \\
\text { exists data is send by } \\
\text { the node otherwise } \\
\text { Route Request packet is } \\
\text { transmitted to } \\
\text { neighboring nodes. } \\
\text { AODV protocol is pure }\end{array}$ & $\begin{array}{l}\text { By performing } \\
\text { modifications in this } \\
\text { protocol congestion in } \\
\text { the network is } \\
\text { controlled and leads to } \\
\text { increase in throughput } \\
\text { by decrease in number } \\
\text { of route request packet. }\end{array}$ \\
\hline
\end{tabular}




\begin{tabular}{|c|c|c|c|c|}
\hline \multirow[t]{2}{*}{ Reactive Routing } & & $\begin{array}{l}\text { LQSR known as Link } \\
\text { Quality Source Routing }\end{array}$ & $\begin{array}{l}\text { on demand routing } \\
\text { protocol. When a source } \\
\text { node wants to send a } \\
\text { data then that node } \\
\text { looks at rout cache for } \\
\text { destination route. If that } \\
\text { node exists then it send } \\
\text { the data otherwise } \\
\text { Route Request Packet is } \\
\text { transmitted. } \\
\text { LQSR is a protocol } \\
\text { derived from DSR } \\
\text { protocol for improving } \\
\text { link quality metrics. } \\
\text { These metrics are hop } \\
\text { count, round trip } \\
\text { latency, packet pair } \\
\text { latency and expected } \\
\text { transmission count. }\end{array}$ & $\begin{array}{l}\text { By adding link quality } \\
\text { metrics these measure } \\
\text { the link quality and this } \\
\text { algorithm follows } \\
\text { piggybacked approach. }\end{array}$ \\
\hline & 4. & $\begin{array}{l}\text { TORA known as } \\
\text { Temporally Ordered } \\
\text { Routing Algorithm }\end{array}$ & $\begin{array}{l}\text { TORA algorithm is free } \\
\text { of loops, highly } \\
\text { adaptive, efficient and } \\
\text { scalable distributed } \\
\text { routing algorithm. }\end{array}$ & $\begin{array}{l}\text { Directed Acyclic Graph } \\
\text { (DAG) is maintained at } \\
\text { each node to every } \\
\text { destination. This } \\
\text { algorithm performs } \\
\text { better under high } \\
\text { mobility simulations. }\end{array}$ \\
\hline Hybrid Protocols & & $\begin{array}{l}\text { ZRP known as Zone } \\
\text { Based Routing Protocol }\end{array}$ & $\begin{array}{l}\text { In ZRP a node's routing } \\
\text { zone is defined where } \\
\text { routing zone is } \\
\text { constructed which } \\
\text { identify all its neighbors } \\
\text { which are one node } \\
\text { away and can reached } \\
\text { directly. }\end{array}$ & $\begin{array}{l}\text { In this protocol } 2 \\
\text { routing methods are } \\
\text { used which are IARP } \\
\text { and IERP. These } \\
\text { methods are used for } \\
\text { constructing and } \\
\text { maintaining the routes } \\
\text { to nodes beyond the } \\
\text { routing zone reactively. }\end{array}$ \\
\hline
\end{tabular}

\section{CONCLUSION}

In this paper, it is been concluded that wireless mesh networks is the decentralized type of network in which mobile nodes join or leave the network when they want. Due to its decentralized nature routing, security and quality of service is the major issue of the network. In this paper, the routing issue is addressed for which various routing protocols are reviewed and compared in terms of various performance parameters

\section{REFERENCES}

[1] Akyildiz, I.F., Wang, X. and Kiyon," A Survey on Wireless Mesh Networks", IEEE Communications Magazine, September 2005, Vol. 43, Issue 9, Page(s) S23-S30.

[2] Akyildiz, I.F., Wang X. and Wang W, "Wireless Mesh Networks: A Survey”, Computer Networks Journal (Elsevier), March 2005, Page(s) 445-487.

[3] S. Siva Nageswara Rao, Y. K. Sundara Krishna, and K.Nageswara Rao, “A Survey: Routing Protocols for Wireless Mesh Networks", IJRRWSN Vol. 1, No. 3.

[4] Adebanjo Adekiigbe, Kamalrulnizam Abu Bakar and Simeon Olumide Ogunnusi, "A Survey of Routing Metrics in Cluster-Based Routing Protocols for Wireless Mesh Networks", Journal of Computing, Vol.3. Issue 8, August 2011.

[5] Kae Won Choi, Wha Sook Jeon, and Dong Geun Jeong, "Efficient Load-Aware Routing Scheme for Wireless Mesh Networks," IEEE Transactions on Mobile Computing, Vol. 9, No. 9, September 2010.

[6] T. Clausen and P. Jacquet. RFC 3626: "Optimized Link State Routing Protocol (OLSR)", Oct 2003.

[7] Birinder Singh, Dr. Gurpal Singh, "Performance Evaluation and Optimization of DSR Routing Algorithm over 802.11 based Wireless Mesh Network", International Journal on Computer Science and Engineering, Vol. 3 No. 5 May 2011.

[8] Kum, Dong-Won kum, Anh-Ngoc Le, You-Ze Cho, Keong Toh, In-Soo Lee, "An Efficient On-Demand Routing Approach with Directional Flooding for Wireless Mesh Networks", Journal of Communications and Networks, Feb 2010, vol. 12, Page(s): 67-73. 
[9] Eiman Alotaibi, Biswanath Mukherjee, "A survey on routing algorithms for wireless Ad-Hoc and mesh networks", Computer Networks, Vol. 56, February 2012, Page(s):940-965.

[10] Zakrzewska A, Koszalka L., Pozniak-Koszalka, "Performance study of Routing Protocols for Wireless Mesh Networks", 19th International Conference of Systems Engineering, 2008.

[11] C. E. Perkins and E. M. Royer, ,Ad Hoc On demand Distance Vector Routing, ' In Proceedings of the 2nd IEEE Work-shop on Mobile Computing Systems and Applications, New Orleans, LA, February 1999, pp. 90-100. C. E. Perkins and P. Bhagwat, ,Highly Dynamic Destination- Sequenced Distance Vector Routing (DSDV) for Mobile Computers, ' SIGCOMM, London, UK, August 1994, pp. 234-244.

[12] D. B. Johnson and D. A. Maltz, ,Dynamic Source Routing in Ad-Hoc Ad hoc Networks," Mobile Computing, ed. T. Imie-linski and H. Korth, Kluwer Academic Publishers, 1996, pp. 153-181.

[13] Charles E. Perkins, Ad Hoc Networking, Addison-Wesley, March 2005.

[14] N. Nikaein, H. Labiod, and C. Bonnet. DDR Distributed Dynamic Routing Algorithm for Mobile Ad hoc Networks. First Annual Work shop on Mobile and Ad Hoc Networking and Computing (MobiHOC),2000.

[15] P.Selvakumar "A Performance Analysis of TORA, AODV and DSR Routing Protocols in MANET using NS2" International Journal of Scientific \& Engineering Research Volume 3, Issue 6, June-2012 5 ISSN 2229-5518.

[16] CarlosLozano-Garzon "A multi-objective routing protocol for a wireless sensor network using a SPEA2 approach. Recent Advances in Computers, Communications, Applied Social Science and Mathematics ISBN: 978-1-61804-030-5. 